\title{
FUNGSI PERADILAN TATA USAHA NEGARA DALAM MENYELESAIKAN SENGKETA LINGKUNGAN (STUDI GUGATAN ORGANISASI LINGKUNGAN HIDUP)*
}

\author{
Francisca Romana Harjiyatni $^{* *}$ dan Sunarya Raharja***
}

\author{
Bagian Hukum Administrasi Negara, Fakultas Hukum Universitas Janabadra, Yogyakarta \\ Jalan Tentara Rakyat Mataram Nomor 55-57, D.I. Yogyakarta 55231
}

\section{Abstract}

This study aims to analyse: (1) The function of the Administrative Court in providing protection against environmental sustainability; (2) Constraints of the implementation of the administrative court functions in resolving environmental disputes. The results showed that: The function of the Administrative Court in providing protection toward the environment is not optimal yet. Administrative Court Decisions has not provided environmental sustainability because judges tend to be formalistic procedural in using their consideration. This is due to the presence of a number of constraints which include: government decision restrictions in the field of environment that can be disputed in the administrative court, there is no use of the principle of sustainable development as the consideration for the judge in deciding the case, and the judges'less understanding about environmental problems.

Keywords: administrative court, environmental dispute.

\section{Intisari}

Penelitian ini bertujuan untuk menganalisis: (1) fungsi PTUN dalam memberikan perlindungan terhadap kelestarian lingkungan; (2) kendala-kendala pelaksanaan fungsi PTUN dalam menyelesaikan sengketa lingkungan. Hasil penelitian menunjukkan bahwa fungsi PTUN dalam memberikan perlindungan terhadap kelestarian lingkungan adalah belum optimal. Putusan-putusan Pengadilan TUN belum memberikan perlindungan kelestarian lingkungan hidup, karena hakim cenderung bersifat prosedural formalistik dalam menggunakan pertimbangannya. Hal ini disebabkan terdapatnya sejumlah kendala yang meliputi: adanya pembatasan KTUN di bidang lingkungan yang dapat menjadi obyek sengketa di PTUN, belum digunakannya asas pembangunan berkelanjutan sebagai pertimbangan hakim untuk memutus perkara, dan pemahaman hakim yang kurang mengenai persoalan lingkungan hidup.

Kata Kunci: peradilan tata usaha negara, sengketa lingkungan.

\section{Pokok Muatan}

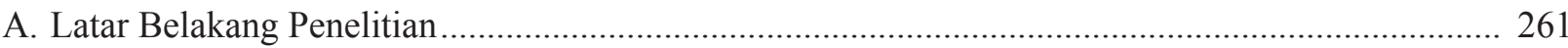

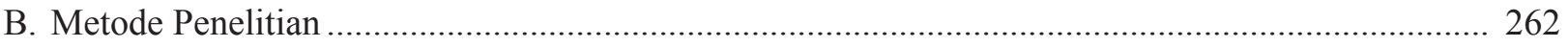

C. Hasil Penelitian dan Pembahasan ........................................................................................... 262

1. Fungsi PTUN dalam Memberikan Perlindungan terhadap Kelestarian Lingkungan ................... 262

2. Kendala-Kendala Apakah yang Muncul dalam Pelaksanaan Fungsi PTUN dalam

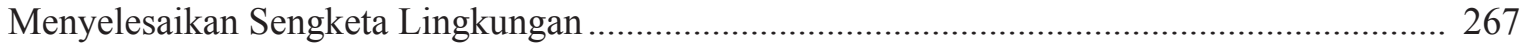

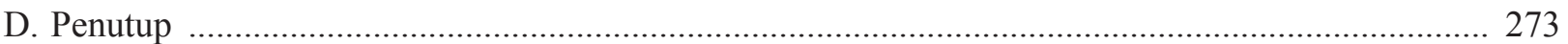

Laporan Penelitian ini didanai oleh Direktorat Penelitian dan Pengabdian Kepada Masyarakat, Direktorat Jenderal Pendidikan Tinggi,

Kementerian Pendidikan dan Kebudayaan Tahun 2013.

**Alamat korespondensi: sisca.rh@gmail.com

**** Alamat korespondensi: sunaryaraharja@yahoo.co.id 


\section{A. Latar Belakang Penelitian}

Negara RI adalah negara hukum. Salah satu ciri negara hukum adalah adanya kekuasaan kehakiman yang merdeka termasuk di dalamnya ada Peradilan Tata Usaha Negara. ${ }^{1}$ Peradilan Tata Usaha Negara (selanjutnya disingkat dengan PTUN) dibentuk dalam rangka memberikan perlindungan kepada masyarakat pencari keadilan, yang merasa dirinya dirugikan akibat suatu Keputusan Tata Usaha Negara (selanjutnya disingkat dengan KTUN). ${ }^{2}$ Berbagai macam KTUN dapat digugat ke PTUN, hal ini disebabkan berbagai macam perbuatan pejabat tata usaha negara seperti perijinan (vergunning), dispensasi, konsesi, dan pengurusan surat-surat dituangkan dalam bentuk keputusan pejabat (beschikking). ${ }^{3}$ Salah satu KTUN yang dapat menjadi obyek sengketa di Pengadilan Tata Usaha Negara adalah izin di bidang lingkungan.

Izin sebagai instrumen yuridis yang digunakan oleh pemerintah untuk mempengaruhi para warga agar mau mengikuti cara yang dianjurkannya guna mencapai suatu tujuan konkrit. Sebagai suatu instrumen, izin berfungsi selaku ujung tombak instrumen hukum sebagai pengarah, perekayasa, dan perancang masyarakat adil dan makmur itu dijelmakan. Persyaratan-persyaratan yang terkandung dalam izin merupakan pengendali dalam memfungsikan izin itu sendiri. ${ }^{4}$ Dalam konteks pengelolaan lingkungan hidup, maka substansi pengelolaan lingkungan hidup hanya dapat berhasil menunjang terwujudnya sistem pembangunan berkelanjutan (sustainable development), apabila administrasi pemerintahan dapat berfungsi secara efektif dan terpadu. Salah satu sarana yuridis administratif untuk mencegah dan menanggulangi adanya pencemaran dan perusakan lingkungan adalah melalui sistem perizinan. Perizinan adalah merupakan instrumen kebijaksanaan lingkungan yang paling mendasar yang ditujukan untuk dapat menjaga kepentingan lingkungan dan keseimbangan ekologis, yang pada akhirnya tetap dapat dinikmati oleh generasi sekarang dan generasi mendatang. ${ }^{5}$

Dalam prakteknya sistem perijinan belum mampu berfungsi sebagai pengendali agar suatu usaha dan/atau kegiatan tidak menimbulkan pencemaran dan kerusakan lingkungan. Suatu usaha dan/atau kegiatan yang diperkirakan mempunyai potensi besar dan menimbulkan dampak negatif terhadap lingkungan dinilai layak lingkungan dan diberikan izin. Dalam kasus lain, suatu usaha dan/ atau kegiatan yang telah dilengkapi dengan izin, dalam pelaksanaannya seringkali menimbulkan dampak berupa pencemaran dan/atau kerusakan lingkungan. Dalam hal yang demikian, organisasi lingkungan hidup dapat menggugat pejabat yang mengeluarkan KTUN untuk usaha dan/atau kegiatan yang berpotensi atau telah menimbulkan dampak negatif terhadap lingkungan hidup tersebut ke Pengadilan TUN. Dalam sengketa lingkungan tersebut, organisasi lingkungan hidup memohon agar KTUN untuk usaha dan/atau kegiatan tersebut dinyatakan batal atau tidak sah dan memerintahkan kepada tergugat untuk mencabut KTUN tersebut. Dengan dicabutnya KTUN untuk usaha dan/ atau kegiatan tersebut, diharapkan kegiatan dan/atau usaha yang menimbulkan kerusakan atau pencemaran lingkungan tidak terjadi atau dihentikan, sehingga kelestarian lingkungan dapat tetap terpelihara.

Maksud adanya peradilan adalah memberikan keadilan kepada para pihak dan demikian menghilangkan sengketa. Sengketa merupakan sesuatu yang mengganggu ketentraman, tata tertib, dan kedamaian masyarakat, sehingga keseimbangan masyarakat tergoncang karenanya. ${ }^{6}$ Dengan adanya peradilan termasuk PTUN

Sri Pudyatmoko dan Riawan Tjandra, 1996, Peradilan Tata Usaha Negara sebagai Salah Satu Fungsi Kontrol Pemerintah, Penerbitan Universitas Atma Jaya, Yogyakarta, hlm. 14.

Muchsan, 1997, Sistem Pengawasan terhadap Perbuatan Aparat Pemerintah dan Peradilan Tata Usaha Negara di Indonesia, Liberty, Yogyakarta, hlm. 57.

Ibid., hlm. 14.

Ridwan, H.R., 2003, Hukum Administrasi Negara, UII Press Yogyakarta, hlm. 160.

Mukhlish dan Mustafa Lutfi, 2010, Hukum Administrasi Lingkungan Kontemporer, Setara Press (Kelompok In-TRANS Publishing), Malang, hlm. 89-90.

Rochmat Soemitro, 1998, Peradilan Tata Usaha Negara, Refika Aditama, Bandung, hlm. 4. 
diharapkan kegoncangan dalam masyarakat akibat kerusakan atau pencemaran lingkungan hidup dapat dipulihkan. Namun demikian, sengketasengketa lingkungan yang telah diselesaikan oleh PTUN dalam kenyataannya belum menghilangkan konflik yang ada. Kegiatan dan/atau usaha yang berpotensi atau telah menimbulkan pencemaran dan kerusakan lingkungan tetap mengantongi ijin dan tetap menjalankan usaha dan/atau kegiatannya. Pencemaran atau kerusakan lingkungan masih terus berlangsung yang menimbulkan ancaman terhadap kelestarian lingkungan. Berdasarkan hal-hal yang telah diuraikan dalam paragraf-paragraf sebelumnya, maka ada dua pertanyaan yang ingin dijawab dalam penelitian ini yaitu: Pertama, bagaimanakah fungsi PTUN dalam memberikan perlindungan terhadap kelestarian lingkungan? Kedua, apa saja kendala-kendala yang muncul dalam pelaksanaan fungsi PTUN dalam menyelesaikan sengketa lingkungan?

\section{B. Metode Penelitian}

Penelitian ini merupakan penelitian hukum normatif. Menurut Mukti Fajar dan Yulianto Achmad, penelitian hukum normatif adalah penelitian hukum yang meletakkan hukum sebagai sebuah bangunan sistem norma. Sistem norma yang dimaksud adalah asas-asas, norma, kaidah dari peraturan perundang-undangan, putusan pengadilan, perjanjian serta doktrin (ajaran). ${ }^{7}$ Untuk akurasi data, penelitian ini juga didukung dengan data yang diperoleh dari penelitian lapangan. Penelitian ini mengambil lokasi Provinsi DKI Jakarta. Adapun pemilihan lokasi penelitian tersebut didasarkan atas pertimbangan bahwa banyak perizinan lingkungan yang dikeluarkan oleh Kementerian Lingkungan Hidup maupun pejabat pusat lainnya yang menimbulkan sengketa lingkungan yang dimintakan penyelesaiannya melalui PTUN Jakarta.

Data primer diperoleh dari hasil wawancara terhadap sejumlah narasumber. Narasumber yang ditentukan dalam penelitian ini adalah: Hakim
Pengadilan TUN Jakarta, Hakim Pengadilan Tinggi TUN Jakarta, Hakim Mahkamah Agung, Pejabat Kementerian Lingkungan Hidup, dan WALHI. Ada dua hal yang akan diteliti dalam penelitian ini, yaitu variabel yang bersifat bebas dan variabel yang bersifat tergantung. Variabel yang bersifat bebas adalah fungsi Peradilan Tata Usaha Negara, sedangkan variabel yang bersifat tergantung adalah penyelesaian sengketa lingkungan. Dalam penelitian ini akan dianalisis hubungan antara fungsi Peradilan Tata Usaha Negara dengan upaya penyelesaian sengketa. Sehubungan dengan penelitian ini merupakan penelitian hukum normatif, hubungan kedua hal tersebut yang konkritnya berbentuk pengaruh hal yang bebas terhadap hal yang tergantung, tidak dianalisis secara statistik, melainkan dianalisis secara kualitatif.

\section{Hasil Penelitian dan Pembahasan \\ 1. Fungsi PTUN dalam Memberikan Perlin- dungan terhadap Kelestarian Lingkungan}

Fungsi PTUN dalam penyelesaian sengketa lingkungan tidak hanya memberikan perlindungan hukum kepada orang atau badan hukum perdata yang dirugikan sebagai pencari keadilan, PTUN juga memberikan perlindungan hukum kepada lingkungan hidup yang menderita kerusakan karena dikeluarkannya KTUN untuk dilakukannya suatu usaha dan/atau kegiatan yang menimbulkan dampak negatif terhadap lingkungan hidup. Dalam hal lingkungan hidup yang menderita karena telah terjadi pencemaran dan/atau kerusakan lingkungan hidup, maka lingkungan hidup diwakili oleh lembaga swadaya masyarakat (LSM) yang bergerak di bidang lingkungan hidup (organisasi lingkungan hidup) dapat menggugat pejabat dan/atau badan tata usaha negara ke Pengadilan TUN karena pejabat dan/atau badan yang bersangkutan telah memberikan izin kepada perusahaan yang kegiatannya potensial atau telah menimbulkan pencemaran dan/atau kerusakan terhadap lingkungan hidup.

Dasar hak gugat organisasi lingkungan hidup 
adalah Pasal 92 Undang-Undang No. 32 Tahun 2009 tentang Perlindungan dan Pengelolaan Lingkungan Hidup yang menyebutkan bahwa:

(1) Dalam rangka pelaksanaan tanggung jawab perlindungan dan pengelolaan lingkungan hidup, organisasi lingkungan hidup berhak mengajukan gugatan untuk kepentingan pelestarian fungsi lingkungan hidup.

(2) Hak mengajukan gugatan terbatas pada tuntutan untuk melakukan tindakan tertentu tanpa adanya tuntutan ganti rugi, kecuali biaya atau pengeluaran riil.

(3) Organisasi lingkungan hidup dapat mengajukan gugatan apabila memenuhi persyaratan: (a) berbentuk badan hukum; (b) menegaskan di dalam anggaran dasarnya bahwa organisasi tersebut didirikan untuk kepentingan pelestarian fungsi lingkungan hidup; dan (c) telah melaksanakan kegiatan nyata sesuai dengan anggaran dasarnya paling singkat 2 (dua) tahun.

Diberikannya hak gugat terhadap organisasi lingkungan hidup, diharapkan organisasi lingkungan hidup tersebut dapat berperan dalam memperjuangkan upaya pelestarian lingkungan melalui pengadilan, termasuk di antaranya melalui Pengadilan Tata Usaha Negara. Menurut Aan Effendi, penyelesaian sengketa lingkungan melalui PTUN memiliki kelebihan-kelebihan bila dibandingkan dengan penyelesaian sengketa lingkungan di peradilan umum, baik itu melalui gugatan perdata maupun tuntutan secara pidana. Penyelesaian sengketa melalui PTUN adalah bertujuan untuk membatalkan izin lingkungan yang dimiliki oleh suatu usaha dan/atau kegiatan. Dengan dibatalkannya izin lingkungan tersebut berarti suatu usaha dan/atau kegiatan tidak dapat melanjutkan lagi usaha dan/atau kegiatannya sehingga sumber pencemarannya dapat dihentikan. ${ }^{8}$ Di dalam praktiknya, kelebihan yang disampaikan Aan Effendi ini sulit untuk direalisasikan melalui gugatan organisasi lingkungan hidup. Gugatangugatan yang diajukan oleh organisasi lingkungan hidup ke PTUN sering mengalami kegagalan dalam memperjuangkan kelestarian lingkungan hidup.

Organisasi lingkungan hidup yang sering mengajukan gugatan ke PTUN untuk kepentingan kelestarian lingkungan hidup adalah Wahana Lingkungan Hidup Indonesia (selanjutnya disingkat dengan WALHI). Ada beberapa gugatan yang diajukan oleh WALHI ke PTUN yang telah diputus oleh pengadilan dan telah memperoleh kekuatan hukum tetap. Berdasarkan analisis dari putusan-putusan PTUN yang memutus mengenai sengketa lingkungan yang digugat oleh organisasi lingkungan hidup, menunjukkan bahwa PTUN belum memberikan perlindungan terhadap kelestarian lingkungan secara maksimal. Hal ini bisa dilihat dari analisis terhadap putusan-putusan PTUN berikut di bawah ini.

\section{a. Putusan PTUN Jakarta No. 145/G/2011/PTUN.JKT}

Dalam perkara ini yang menggugat adalah Wahana Lingkungan Hidup Indonesia (WALHI) dan Gerakan Masyarakat Cinta Alam "GemaAlam", sedangkan yang menjadi tergugat adalah Menteri Lingkungan Hidup dan PT Newmont Nusa Tenggara sebagai tergugat II intervensi. Yang menjadi obyek gugatan dalam perkara ini Surat Keputusan Menteri Negara Lingkungan Hidup Nomor 92 Tahun 2011 mengenai pemberian Izin Penempatan Tailing di Dasar Laut kepada PT Newmont Nusa Tenggara pada Proyek Batu Hijau pada tanggal 9 Mei 2011.

Alasan-alasan Wahana Lingkungan Hidup Indonesia (WALHI) dan Gerakan Masyarakat Cinta Alam "Gema Alam" menggugat adalah sebagai berikut: Pertama,

\footnotetext{
Aan Effendi, "Penyelesaian Sengketa Lingkungan Melalui Peradilan Tata Usaha Negara”, Perspektif, Vol. XVIII, No. 1, Januari 2013, hlm. 15.
} 
bahwa dengan diterbitkannya Objek Sengketa TUN yang memberikan izin kepada Tergugat II Intervensi untuk melakukan pembuangan tailing ke Laut Teluk Senunu, mengakibatkan pencemaran dan kerusakan lingkungan hidup. Oleh karena kepentingan Para Penggugat sebagai Organisasi Lingkungan Hidup dirugikan dengan diterbitkannya KTUN Objek Sengketa sesuai dengan pasal 53 ayat (1) UU PTUN, maka Gugatan ini diajukan kepada Tergugat, dimana gugatan ini merupakan hak gugat organisasi lingkungan hidup yang diatur dalam Pasal 92 UUPPLH.

Dalam perkara ini hakim memutuskan "menyatakan gugatan para penggugat dinyatakan tidak diterima". Pertimbangan hakim dalam putusan tersebut adalah bahwa keputusan tersebut sudah sesuai dengan peraturan pemerintahan yang ada, selain itu Gema Alam dianggap tidak memiliki legal standing untuk mengajukan tuntutan. Terhadap putusan PTUN Jakarta tersebut diajukan banding ke PT TUN Jakarta. Dalam tingkat banding ini pun, WALHI dan Gerakan Masyarakat Cinta Alam sebagai penggugat dan Bupati Sumbawa sebagai tergugat II intervensi adalah sebagai pihak yang dikalahkan, di mana Putusan PT TUN Jakarta menguatkan terhadap Putusan PTUN Jakarta.

Dengan putusan yang demikian, hakim cenderung bersifat formalistik positivistik karena hanya melihat obyek gugatan memenuhi kualifikasi sebagai KTUN yang dapat digugat ke PTUN atau tidak, atau hanya melihat penggugat memenuhi kualifikasi sebagai penggugat atau tidak. Hakim tidak menilai lebih jauh mengenai substansi pokok perkaranya, sehingga aspek lingkungan dalam perkara TUN seperti ini kurang dinilai lebih jauh oleh hakim. Dengan demikian dapat disimpulkan persoalan kelestarian lingkungan tidak tersentuh sama sekali dalam putusan tersebut. Hal ini menyebabkan perlindungan kelestarian lingkungan yang diharapkan diperoleh melalui PTUN kurang dapat diwujudkan secara optimal.

\section{b. Putusan Mahkamah Agung 12/PK/ TUN/2011}

Para pihak dalam perkara TUN ini adalah para pengusaha yang melakukan kerjasama/nota kesepahaman dengan Badan Pengelola Pantura untuk melakukan reklamasi dan revitalisasi kawasan pantura di satu pihak melawan Menteri Negara Lingkungan Hidup RI, Wahana Lingkungan Hidup Indonesia (WALHI), Asosiasi Penasehat Hukum dan HAM Indonesia (APHI), Perhimpunan Bantuan Hukum dan HAM (PBHI), Indonesian Center for Environmental Law (ICEL) di pihak lainnya.

Obyek gugatan dalam perkara ini adalah Surat Keputusan Menteri Negara Lingkungan Hidup No. 14 Tahun 2003 tentang Ketidaklayakan Rencana Kegiatan Reklamasi dan Revitalisasi Pantura. Dengan terbitnya surat keputusan tersebut, para pengusaha merasa dirugikan karena tidak mendapatkan ijin dan tidak dapat menjalankan usahanya. Atas dasar hal tersebut, para pengusaha menggugat ke Pengadilan TUN Jakarta agar Keputusan Menteri itu dinyatakan batal atau tidak sah.

Atas gugatan penggugat tersebut, PTUN Jakarta memutuskan mengabulkan gugatan penggugat seluruhnya, menyatakan Keputusan Menteri LH tersebut tidak sah, dan memerintahkan Menteri LH untuk mencabut keputusan tersebut. Atas Putusan Pengadilan TUN tersebut, tergugat mengajukan banding ke PT TUN Jakarta, dan PT TUN Jakarta memutuskan: (1) menolak eksepsi tergugat/pembanding seluruhnya; (2) menguatkan Putusan Pengadilan TUN Jakarta No. No. 75/G.TUN/2003/PTUNJKT. Atas putusan banding tersebut Tergugat/ Pembanding mengajukan kasasi ke MA, dan MA memutuskan: (1) menerima permohonan kasasi pemohon Menteri Negara Lingkungan 
Hidup; (2) membatalkan putusan Pengadilan Tinggi Tata Usaha Negara Jakarta No. 202/B/2004/PT.TUN-JKT. Terhadap putusan kasasi tersebut kemudian diajukan upaya Peninjauan Kembali ke MA, dan MA memutuskan: (1) mengabulkan gugatan para penggugat seluruhnya; (2) menyatakan tidak sah Surat Keputusan Tergugat No. 14 Tahun 2003 tentang Ketidaklayakan Rencana Kegiatan Reklamasi dan Revitalisasi Pantai Utara Jakarta oleh Badan Pelaksana Pantai Utara Jakarta di Propinsi DKI Jakarta; (3) mewajibkan kepada Tergugat untuk mencabut Surat Keputusan No. 14 Tahun 2003 tentang Ketidaklayakan Rencana Kegiatan Reklamasi dan Revitalisasi Pantai Utara Jakarta di Propinsi DKI Jakarta.

Dalam Putusan MA No. 12/PK/ TUN/2011 tersebut, Majelis Hakim yang memeriksa dalam Peninjauan Kembali menyimpulkan bahwa terdapat kekeliruan/ kekhilafan nyata dalam pertimbangan putusan judex juris dengan kesimpulan bahwa Keputusan Tata Usaha Negara yang menjadi obyek sengketa tidak mempunyai sifat final akan tetapi hanya rekomendasi. Sebaliknya dalam putusan peninjauan kembali tersebut hakim mempunyai pertimbangan sebagai berikut:

1) Keputusan Tata Usaha Negara Obyek sengketa sudah bersifat final karena tidak diperlukan persetujuan lebih lanjut dari instansi atasan Tergugat/Termohon Peninjauan Kembali, dan Keputusan Tata Usaha Negara obyek sengketa menyebutkan: "Berdasarkan Keputusan ini, maka instansi yang berwenang wajib menolak permohonan izin melakukan usaha dan atau kegiatan". Keputusan Tata Usaha Negara obyek sengketa tersebut bersifat individual ditujukan ke- pada jabatan yang berwenang menerbitkan izin usaha atau kegiatan, dan menimbulkan akibat hukum, karena dengan terbitnya Keputusan Tata Usaha Negara obyek sengketa praktis semua kegiatan Reklamasi Pantai Utara menjadi terhenti, sehingga keadaan tersebut merugikan kepentingan Para Penggugat (Pemohon Peninjauan Kembali/ sebagai badan hukum perdata).

2) Keputusan Tata Usaha Negara obyek sengketa telah memenuhi persyaratan sebagai obyek sengketa dalam Peradilan Tata Usaha Negara berdasarkan Pasal 1 butir 3 Undang-Undang No. 5 Tahun 1986 sebagaimana telah diubah dengan Undang-Undang No. 9 Tahun 2004 dan perubahan kedua dengan Undang-Undang No. 51 Tahun 2009.

3) Apabila benar proses reklamasi Pantai Utara terdapat kelemahan dari segi Amdal, karena kegiatannya berdasarkan Keppres No. 52 Tahun 1995 dan Tergugat (Menteri Negara Lingkungan Hidup) sebagai Tim Pengarah, maka perubahan dan penghentian kegiatan harus melalui lembaga Keputusan Presiden (in casu kemudian disempurnakan dengan Peraturan Presiden No. 54 Tahun 2007) akan tetapi bukan dengan Keputusan Menteri.

Dalam dua putusan tersebut WALHI sebagai pihak yang dikalahkan baik sebagai tergugat intervensi dalam Putusan MA No. 12/PK/TUN/2011 maupun sebagai penggugat dalam Putusan Pengadilan TUN Jakarta No. 145/G/2011/PTUN-JKT (yang dikuatkan dengan Putusan PT TUN Jakarta tanggal 
13 September 2013). Ini menunjukkan pertimbangan dari aspek kelestarian lingkungan kurang diperhatikan oleh hakim, dan putusan-putusan tersebut cenderung lebih memihak kepada pemilik modal besar.

Kalau Putusan MA No. 12/PK/ TUN/2011 dibandingkan dengan Putusan Pengadilan TUN Jakarta No. 187/G/2009/ PTUN- JKT (yang dikuatkan dengan Putusan PT TUN Jakarta No. 176/B/2010/PT.TUN. JKT dan dikuatkan lagi dengan Putusan Mahkamah Agung No. 442-K-TUN-2007) ada kejanggalan dalam pertimbangan hakimnya dan menunjukkan hakim tidak berpihak pada upaya perlindungan terhadap kelestarian lingkungan. Dalam Putusan Pengadilan TUN Jakarta No. 187/G/2009/PTUN-JKT, sebagai penggugat adalah 8 (delapan) orang warga masyarakat di Kecamatan Likupang Timur, Kabupaten Minahasa Utara, Provinsi Sulawesi Utara, dan Kecamatan Ranowolu, Kota Bitung, Provinsi Sulawesi Utara. Tergugat dalam perkara ini adalah Menteri Negara Lingkungan Hidup RI sebagai Tergugat dan PT Meares Soputan Mining sebagai Tergugat II intervensi 1 serta PT Tambang Tondano Nusajaya sebagai Tergugat II intervensi 2.

Yang menjadi obyek gugatan dalam perkara tersebut adalah: (1) Keputusan Menteri Negara Lingkungan Hidup Republik Indonesia Nomor 523 Tahun 2009 tentang Kelayakan Lingkungan Hidup Rencana Kegiatan Penambangan Emas Tokat Indung di Kabupaten Minahasa Utara dan Kota Bitung Provinsi Sulawesi Utara oleh PT Meares Soputan Mining tertanggal 5 Oktober 2009; (2) Keputusan Menteri Negara Lingkungan Hidup Republik Indonesia Nomor 524 Tahun 2009 tentang Kelayakan Lingkungan Hidup Rencana Kegiatan Penambangan Emas Batupangah di Kabupaten Minahasa Utara dan Kota Bitung Provinsi Sulawesi Utara oleh PT Tambang Tondano Nusajaya tertanggal 5 Oktober 2009. Menurut para penggugat KTUN ini memenuhi kriteria KTUN yang diatur Pasal 1 ayat (3) UndangUndang No. 5 Tahun 1986 yaitu penetapan tertulis yang dikeluarkan pejabat atau badan TUN yang berisi tindakan hukum tata usaha negara, bersifat konkret, individual, dan final, yang menimbulkan akibat hukum terhadap seseorang atau badan hukum perdata.

Dalam Putusan MA No. 12/ PK/TUN/2011, hakim menilai bahwa Keputusan Menteri Negara Lingkungan Hidup tentang Ketidaklayakan lingkungan sebagai KTUN yang final dan memenuhi kriteria KTUN seperti yang diatur dalam Pasal 1 ayat (3) Undang-Undang No. 5 Tahun 1986, sehingga memenangkan para penggugat yang dalam hal ini adalah para pengusaha. Sedangkan Putusan Pengadilan TUN Jakarta No. 187/G/2009/PTUN-JKT yang dikuatkan oleh PT TUN Jakarta dan Putusan Kasasi Mahkamah Agung, Hakim menilai bahwa Keputusan Menteri Negara Lingkungan Hidup mengenai Kelayakan Lingkungan sebagai KTUN yang belum final dan tidak memenuhi kriteria KTUN seperti yang diatur dalam Pasal 1 ayat (3) Undang-Undang No. 5 Tahun 1986, sehingga dalam hal ini penggugat yang adalah warga masyarakat dikalahkan dan tergugat Menteri Lingkungan Hidup dan perusahaan sebagai tergugat intervensi dimenangkan. Hal ini tentu saja dapat menimbulkan ketidakpastian hukum, karena terhadap obyek yang sama dinilai secara bertentangan dan lebih mementingkan kepentingan pemilik modal besar. Dalam penyempurnaan peraturan perundang-undangan berikutnya harus ada kejelasan apakah "Keputusan Menteri Lingkungan Hidup mengenai kelayakan atau ketidaklayakan lingkungan hidup" memenuhi kualifikasi sebagai KTUN yang dapat dijadikan obyek sengketa atau tidak, sehingga tidak ditafsirkan sesuka hati demi kepentingan pihak tertentu saja. 


\section{Kendala-Kendala Apakah yang Muncul dalam Pelaksanaan Fungsi PTUN dalam Menyelesaikan Sengketa Lingkungan}

Pelaksanaan fungsi PTUN dalam menyelesaikan sengketa lingkungan sudah sesuai dengan hukum acara yang berlaku, meskipun demikian belum optimal dalam memberikan terhadap kelestarian lingkungan. Hal ini disebabkan adanya beberapa kendala, baik kendala peraturan perundang-undangan, kendala terhadap asas-asas hukum, dan kendala terhadap pelaksana hukum.

\section{a. Kendala Peraturan Perundangan- Undangan}

Kebanyakan perkara lingkungan yang diajukan ke pengadilan termasuk yang diajukan dan diputus oleh Pengadilan Tata Usaha Negara baik yang diajukan oleh masyarakat yang terkena dampak oleh suatu usaha dan/atau kegiatan maupun yang diajukan oleh organisasi lingkungan hidup gagal untuk mendapatkan keadilan. Hal ini disebabkan adanya kendala peraturan perundang-undangan. Kendala pertama adalah adanya pembatasan KTUN di bidang lingkungan hidup yang dapat diajukan ke Pengadilan TUN. Berdasarkan Pasal 1 butir 3 Undang-Undang No. 5 Tahun 1986, KTUN yang dapat digugat ke PTUN jika memenuhi unsur-unsur sebagai berikut: (1) berbentuk penetapan tertulis; (2) dibuat oleh Pejabat TUN atau Badan TUN; (3) mendasarkan pada peraturan perundang-undangan yang berlaku; (4) bersifat konkrit, individual, dan final; (5) menimbulkan akibat hukum pada seseorang atau badan hukum perdata.

KTUN di bidang lingkungan hidup yang dapat digugat ke PTUN harus memenuhi unsur-unsur KTUN seperti yang diatur dalam Pasal 1 ayat (3) Undang-Undang No. 5 Tahun 1986 tersebut. Selain harus memenuhi unsurunsur tersebut di atas, suatu KTUN dapat menjadi obyek sengketa TUN di bidang lingkungan hidup apabila memenuhi kriteria KTUN yang diatur dalam Pasal 93 ayat
(1) UU PPLH. Pasal 93 ayat (1) UU PPLH mengatakan bahwa:

Setiap orang dapat mengajukan gugatan terhadap keputusan tata usaha negara apabila:

a. Badan atau pejabat tata usaha negara menerbitkan izin lingkungan kepada usaha dan/ atau kegiatan yang wajib amdal tetapi tidak dilengkapi dengan dokumen AMDAL.

b. Badan atau pejabat tata usaha negara menerbitkan izin lingkungan kepada kegiatan yang wajib UKL-UPL, tetapi tidak dilengkapi dengan dokumen UKL-UPL; dan/atau.

c. Badan atau pejabat tata usaha negara yang menerbitkan izin usaha dan/atau kegiatan yang tidak dilengkapi dengan izin lingkungan.

Berdasarkan ketentuan tersebut, dapat disimpulkan bahwa KTUN yang dapat digugat ke PTUN dibatasi pada tiga hal yaitu:

1) KTUN berupa izin lingkungan yang ditujukan untuk usaha dan/atau kegiatan yang wajib AMDAL tetapi tidak dilengkapi dengan dokumen AMDAL.

2) KTUN berupa izin lingkungan untuk kegiatan yang wajib dilengkapi UKL-UPL tetapi tidak dilengkapi dengan dokumen UKL-UPL.

3) KTUN berupa izin usaha dan/ atau kegiatan yang tidak dilengkapi dengan izin lingkungan.

Dengan demikian KTUN di bidang lingkungan di luar yang disebutkan di atas tidak dapat digugat ke Pengadilan TUN. Keputusan-keputusan seperti dokumendokumen AMDAL itu sendiri misalnya dokumen RKL dan RPL, izin lingkungan 
yang dilengkapi dengan AMDAL, izin lingkungan yang dilengkapi dengan UKLUPL, izin usaha yang dilengkapi dengan izin lingkungan tidak dapat digugat ke Pengadilan TUN. Padahal dimungkinkan KTUN seperti tersebut diatas berpotensial merugikan warga masyarakat atau memberikan ancaman terhadap kelestarian lingkungan hidup.

Hal yang demikian menyebabkan PTUN belum mampu menjalankan fungsinya dalam menyelesaikan sengketa lingkungan dengan baik dan dapat memberikan perlindungan terhadap kelestarian lingkungan. Dalam upaya pelestarian lingkungan, yang diutamakan adalah upaya pencegahan supaya pencemaran dan/atau kerusakan lingkungan tidak terjadi. Yang paling bijaksana dilakukan dalam upaya pelestarian lingkungan adalah menerapkan prinsip kehati-hatian sehingga dapat mencegah pencemaran dan/atau kerusakan tidak terjadi yang dikenal dengan "precautionary principle". Ini didasarkan pada pandangan bahwa lebih baik mencegah terjadinya pencemaran dan kerusakan lingkungan daripada mengatasi pencemaran dan kerusakan yang telah terjadi. Biaya pemulihan akibat pencemaran dan/atau kerusakan lingkungan jauh lebih besar daripada mencegah terjadinya pencemaran dan/atau kerusakan lingkungan. Oleh karena itu, dengan tertutupnya menggugat keputusan yang berupa dokumen AMDAL tersebut berarti menutup upaya untuk mencegah terjadinya pencemaran dan/atau kerusakan lingkungan. Apabila dokumen AMDAL dibuat tidak sesuai dengan prosedur yang ditentukan atau materinya/substansinya potensial menimbulkan dampak terhadap lingkungan, seharusnya dapat digugat ke Pengadilan TUN. Apabila AMDAL dibatalkan atau dinyatakan tidak sah, maka usaha dan/kegiatan tersebut tidak mendapatkan izin, yang berarti usaha dan/atau kegiatan yang diperkirakan menimbulkan dampak tersebut tidak beroperasi dan pencemaran atau kerusakan lingkungan dapat dicegah supaya tidak terjadi.

Demikian halnya dengan izin lingkungan yang sudah dilengkapi AMDAL, dengan berjalannya usaha dan/atau kegiatan, dimungkinkan usaha dan/atau kegiatan dilaksanakan tidak sesuai dengan dokumen AMDAL sehingga menimbulkan pencemaran dan kerusakan lingkungan. Dalam hal terjadi demikian, perseorangan yang dirugikan atau organisasi lingkungan tidak dapat menggugat ke PTUN karena terganjal ketentuan tersebut, di mana KTUN izin lingkungan dapat digugat ke PTUN apabila tidak dilengkapi AMDAL, padahal faktanya kegiatan dan/atau usaha yang telah dilengkapi AMDAL tersebut aktivitasnya menimbulkan pencemaran dan/ atau kerusakan lingkungan. Dengan ketentuan tersebut, maka menutup kemungkinan untuk menggugat ke PTUN sangat kecil, kalaupun gugatan tetap diajukan ke PTUN, hakim akan menggunakan ketentuan tersebut dalam pertimbangan putusannya bahwa KTUN yang digugat tidak memenuhi kualifikasi KTUN bidang lingkungan yang dapat digugat ke PTUN berdasarkan Pasal 93 ayat (1) UU PPLH. Hal ini tentu saja akan menyebabkan upaya perlindungan terhadap kelestarian lingkungan dalam sengketa lingkungan tidak dapat difungsikan dengan baik oleh PTUN.

Demikian juga dengan kegiatan dan/atau usaha yang sudah dilengkapi dengan UKL-UPL, dimungkinkan untuk menimbulkan pencemaran dan kerusakan lingkungan yang merugikan perseorangan atau membahayakan kelestarian lingkungan, tidak dapat digugat ke PTUN karena terganjal ketentuan Pasal 93 ayat (1) UU PPLH. Seperti kegiatan dan/atau usaha yang sudah dilengkapi AMDAL, apabila usaha dan/ atau kegiatan yang telah dilengkapi UKLUPL digugatkan ke PTUN, oleh hakim akan diputus gugatan dinyatakan tidak diterima karena KTUN yang digugat tidak memenuhi 
kualifikasi KTUN seperti yang diatur dalam Pasal 93 ayat (1) UU PPLH.

Demikian juga dengan ketentuan dalam Pasal 93 ayat (1) UU PPLH yang intinya bermakna bahwa "izin usaha yang tidak dilengkapi izin lingkungan dapat digugat ke PTUN", ketentuan ini merupakan hambatan bagi perseorangan yang dirugikan atau organisasi lingkungan hidup untuk menggugat ke PTUN guna mendapat perlindungan hukum dan keadilan. Suatu izin usaha meskipun telah dilengkapi izin lingkungan tidak menutup kemungkinan pelaksanaan usaha dan/atau kegiatan tersebut menyebabkan terjadinya pencemaran dan/ atau kerusakan lingkungan. Dalam hal demikian seharusnya jika ada perseorangan yang dirugikan atau organisasi lingkungan yang mewakili untuk kepentingan kelestarian lingkungan dapat meminta perlindungan hukum kepada pengadilan termasuk Pengadilan TUN. Namun, perlindungan hukum yang diharapkan akan sulit didapatkan jika Pengadilan TUN dalam menjalankan fungsinya berpedoman pada ketentuan Pasal 93 ayat (1) UU PPLH tersebut. Dalam hal ini, hakim akan cenderung menyatakan gugatan tidak diterima dengan pertimbangan KTUN yang merupakan obyek sengketa tidak memenuhi kualifikasi KTUN yang ditentukan dalam Pasal 93 (1) UU PPLH. Dalam hal yang demikian hakim, tidak akan memeriksa substansi lebih jauh kasus tersebut dari aspek kelestarian lingkungan namun hanya menilai secara formalistik legalistik.

Kendala peraturan yang lain adalah adanya ketentuan seperti yang diatur dalam Pasal 90 ayat (1) UU PPLH yang berbunyi:

Instansi pemerintah dan pemerintah daerah yang bertanggung jawab di bidang lingkungan hidup berwenang mengajukan gugatan ganti rugi dan tindakan tertentu terhadap usaha dan/ atau kegiatan yang menyebabkan pencemaran dan/atau kerusakan lingkungan hidup yang mengakibatkan kerugian lingkungan hidup.

Dalam penjelasannya tidak dijelaskan lebih lanjut yang dimaksud dengan instansi pemerintah dan pemerintah daerah. Selain itu, juga tidak dijelaskan "instansi pemerintah dan pemerintah daerah" harus menggugat semua atau salah satu saja bisa menggugat. Dalam prakteknya ketentuan dalam peraturan ini ditafsirkan berbeda oleh berbagai pihak termasuk oleh hakim. "Instansi pemerintah dan pemerintah daerah" diartikan harus semua. Ini tidak mungkin, karena jarang pemerintah dan pemerintah daerah mempunyai kepentingan yang sama. Biasanya Pemda tidak mungkin menggugat yang merupakan investasi di daerah, karena itu menguntungkan bagi daerahnya, sehingga tidak mau menggugat bersama-sama pemerintah karena akan merugikan daerah.

b. Kendala terhadap Asas-Asas Hukum

Berdasarkan Pasal 53 ayat (2) UU PTUN, alasan-alasan yang dapat digunakan untuk menggugat ke PTUN adalah:

1) KTUN bertentangan dengan peraturan perundang-undangan yang berlaku.

2) KTUN bertentangan dengan asas-asas umum pemerintahan yang baik. Kedua hal tersebut juga dijadikan oleh hakim sebagai alat untuk menguji KTUN yang digugat itu sah atau tidak. Hakim akan menilai suatu KTUN itu sah atau tidak didasarkan dua hal seperti tersebut di atas.

Berdasarkan alat penguji yang kedua, asas-asas umum pemerintahan yang baik (AAUPB) mengacu pada asas-asas yang diatur dalam Undang-Undang Tahun 1999 yang meliputi asas kepastian hukum, asas tertib penyelenggara negara, asas transparansi, 
asas akuntabilitas, asas proporsionalitas, asas profesionalitas. Namun penyebutan kepada asas-asas tersebut tidak secara limitatif. Hakim bisa menggunakan AAUPB di luar yang diatur dalam Undang-Undang No. 28 Tahun 1999, yaitu AAUPB yang berkembang di dalam praktek penyelenggaraan negara. AAUPB yang berkembang di dalam praktek penyelenggara negara bersifat dinamis dan berubah sesuai kebutuhan di dalam masyarakat. Hakim PTUN seharusnya juga tidak kaku dalam menggunakan AAUPB dalam pengujian KTUN yang digugat. Hakim seharusnya bisa menggunakan asas-asas yang muncul kemudian sejalan perkembangan dan kebutuhan yang ada di dalam masyarakat.

Dalam perkembangannya, untuk mewujudkan kesejahteraan masyarakat muncul suatu asas-asas baru dalam hukum lingkungan seperti asas pembangunan berkelanjutan dan precautionary principle. Mengenai precautionary principle Wikipedia Encyclopedia menyebutkan bahwa:

The precautionary principle or precautionary approach states if an action or policy has a suspected risk of causing harm to the public or to the environment, in the absence of scientific consensus that the action or policy is harmful, the burden of proof that it is not harmful falls on those taking an action. ${ }^{9}$

Berdasarkan pengertian tersebut dapat diketahui bahwa, prinsip pencegahan atau pendekatan pencegahan adalah jika suatu tindakan atau kebijakan memiliki risiko yang diduga menyebabkan kerugian kepada masyarakat atau lingkungan, dengan tidak adanya kajian ilmiah bahwa tindakan atau kebijakan berbahaya, beban pembuktian bahwa itu tidak berbahaya jatuh pada mereka yang mengambil tindakan. Dengan kata lain, prinsip pencegahan dini (precautionary principle) mengandung suatu pengertian bahwa apabila ada ancaman yang berat atau adanya ancaman kerusakan lingkungan yang tidak dapat dipulihkan serta ketiadaan temuan atau pembuktian ilmiah yang konklusif dan pasti, tidak dapat dijadikan alasan untuk menunda upaya untuk mencegah terjadinya kerusakan lingkungan.

Dari pengertian ini, jelas bahwa suatu kegiatan dan/atau usaha yang berpotensi menimbulkan dampak harus dilakukan kajian mengenai dampaknya terlebih dahulu sebelum dilaksanakan. Apabila hasil dari kajian dampak kegiatan dan/atau kegiatan tersebut lebih banyak dampak positifnya kegiatan dan/atau usaha tersebut baru diberi ijin dan dapat dilaksanakan. Berdasarkan "precautionary principle" tersebut, seharusnya kajian AMDAL dapat digugat ke PTUN apabila masyarakat mempunyai pendapat yang berbeda bahwa kegiatan dan/atau usaha tersebut berpotensi untuk menimbulkan dampak yang merugikan apabila usaha dan/atau kegiatan tersebut dilaksanakan, sehingga dengan Putusan Pengadilan TUN kajian AMDAL tersebut dibatalkan sebagai upaya untuk mencegah timbulnya kegiatan dan/atau usaha yang merugikan masyarakat atau merusak lingkungan.

Asas pembangunan berkelanjutan, mempunyai makna bahwa pembangunan dilaksanakan dengan tetap memperhatikan kelestarian lingkungan dan sumber daya alam. Lingkungan dan sumber daya alam merupakan modal suatu negara agar bisa membangun. Apabila lingkungan hidup rusak dan sumber daya alam habis maka pembangunan tidak bisa dilanjutkan dan kesejahteraan rakyat yang merupakan tujuan negara tidak bisa terwujud. Oleh karena itu, dalam melaksanakan pembangunan 
harus diiringi dengan upaya perlindungan terhadap kelestarian lingkungan dan sumber daya alam, sehingga pembangunan bisa terus berlanjut tidak berhenti. Untuk mewujudkan keberhasilan pembangunan untuk mewujudkan kesejahteraan rakyat, maka asas pembangunan berkelanjutan harus menjiwai dalam setiap penyelenggaraan negara dan pemerintahan maupun seluruh rakyat Indonesia. Dalam pembuatan keputusan, Pejabat TUN atau Badan TUN harus mempertimbangkan asas pembangunan berkelanjutan, misalnya dalam pemberian izin usaha dan/atau kegiatan, pejabat pemberi izin harus mempunyai pertimbangan yang cermat sehingga ijin yang dikeluarkan tidak menimbulkankerusakan dan/atau pencemaran lingkungan. Pejabat pembuat peraturan perundang-undangan pun juga harus mampu membuat aturan yang memperhatikan aspek pembangunan berkelanjutan dan tidak hanya memperhatikan kepentingan ekonomi sesaat saja. Hakim pengadilan pun diharapkan melalui putusan-putusannya menciptakan putusan yang mampu memberikan kontribusi dalam mewujudkan pembangunan berkelanjutan.

Dalam hal yang demikian, Hakim Pengadilan TUN dalam menyelesaikan sengketa lingkungan seharusnya menerapkan asas pembangunan berkelanjutan untuk menguji KTUN obyek sengketa, bahkan meskipun itu tidak didalilkan oleh para pihak. Keberanian hakim untuk memutus sengketa lingkungan dengan menggunakan pertimbangan asas pembangunan berkelanjutan di dalam pengujian KTUN yang digugat akan menciptakan asas-asas umum pemerintahan yang baru di dalam praktek. Namun demikian, dalam banyak sengketa lingkungan yang ditangani oleh Pengadilan TUN, hakim hampir belum pernah menggunakan asas pembangunan berkelanjutan untuk menguji KTUN yang digugat, bahkan hakim dalam memutus masih bersifat prosedural formalistik semata. Hakim hanya menguji KTUN memenuhi kualifikasi KTUN yang bisa digugat ke PTUN atau tidak, atau hakim hanya menilai penggugat memenuhi kualifikasi sebagai penggugat atau tidak. Hakim belum banyak menyentuh hingga ke substansi perkaranya menyangkut kelestarian lingkungan.

\section{c. Kendala terhadap Pelaksana Hukum}

Terdapat sejumlah kendala yang menyebabkan PTUN kurang berfungsi secara maksimal dalam menyelesaikan sengketa lingkungan ditinjau dari aspek pelaksana hukum. Yang pertama kendala mengenai pemahaman hakim terhadap substansi mengenai lingkungan hidup. Ini bisa dilihat dari putusan-putusan Pengadilan TUN yang memutus mengenai sengketa lingkungan. Dalam sengketa lingkungan yang diputus oleh Pengadilan TUN, kebanyakan masyarakat yang terkena dampak suatu usaha dan/atau kegiatan atau organisasi lingkungan hidup yang menggugat untuk kepentingan lingkungan sering dikalahkan dan kurang bisa memperjuangkan hak-haknya.

Dalam kasus-kasus seperti ini, hakim dalam pertimbangan putusannya lebih bersifat formalistik legalistik. Putusan Pengadilan TUN kebanyakan memutus gugatan dinyatakan tidak diterima (niet ontvankelijke verklaard/NO), dengan pertimbangan KTUN tidak memenuhi kualifikasi sebagai KTUN yang dapat digugat ke PTUN atau penggugat tidak memenuhi kualifikasi sebagai penggugat yang mempunyai kedudukan untuk menggugat ke PTUN. Dalam hal yang seperti ini, substansi dari pokok perkaranya tidak dinilai oleh hakim, sehingga aspek kepentingan lingkungan tidak dinilai oleh hakim yang pada akhirnya tujuan untuk memperjuangkan hak masyarakat atau kepentingan kelestarian lingkungan tidak tercapai. Hal ini disebabkan 
masalah lingkungan hidup merupakan materi yang tidak setiap hakim menguasai dengan baik. Berdasarkan hasil wawancara dengan Kementerian Lingkungan Hidup RI, pejabat Kementerian Lingkungan Hidup RI mengatakanbahwapemahamanhakim tentang lingkungan kurang, sehingga menyebabkan putusan kurang mempertimbangkan aspek kelestarian lingkungan. Kemudian oleh
Kementerian Lingkungan Hidup bekerjasama dengan Mahkamah Agung memberikan pelatihan mengenai materi lingkungan kepada para hakim dari Pengadilan tingkat I sampai Hakim Agung. Bagi hakim yang lolos diberikan sertifikat. Pelatihan sertifikasi dilakukan mulai tahun 2011 sampai dengan 2013. Materi yang diberikan dalam pelatihan tersebut meliputi:

Tabel 1. Materi Pelatihan Sertifikasi Hakim

\begin{tabular}{|c|c|c|}
\hline No. & Materi & Jam Pelajaran \\
\hline 1 & Judicial Activism & 3 \\
\hline 2 & Paradigma Pembangunan Berkelanjutan & 2 \\
\hline 3 & $\begin{array}{l}\text { Tata Kelola Pemerintahan yang Baik dalam Perlindungan dan Pengelolaan } \\
\text { Lingkungan Hidup }\end{array}$ & 2 \\
\hline 4 & Politik Hukum Perlindungan dan Pengelolaan Lingkungan Hidup & 4 \\
\hline 5 & Alat Bukti dan Kedudukan Ilmiah dalam Perkara Lingkungan Hidup & 2 \\
\hline 6 & Aspek Prosedural dan Substansial Hukum Pidana Lingkungan Hidup & 4 \\
\hline 7 & $\begin{array}{l}\text { Aspek Prosedural dan Substansial Hukum Perdata Lingkungan Hidup dan } \\
\text { SDA }\end{array}$ & 4 \\
\hline 8 & $\begin{array}{l}\text { Penataan Ruang dan Penerapannya dalam Perlindungan dan Pengelolaan } \\
\text { Lingkungan Hidup }\end{array}$ & 4 \\
\hline 9 & $\begin{array}{l}\text { Keterkaitan antara Penegakan Hukum Lingkungan (Pidana, Perdata, dan } \\
\text { Administrasi) }\end{array}$ & 4 \\
\hline 10 & $\begin{array}{l}\text { Aspek Prosedural dan Substansial Hukum Acara Tata Usaha Negara } \\
\text { Lingkungan Hidup dan SDA }\end{array}$ & 4 \\
\hline 11 & Observasi Lapangan & 8 \\
\hline 12 & $\begin{array}{l}\text { Scientific dan Legal Evidence: Aspek Pencemaran Lingkungan Akibat } \\
\text { Kegiatan Industri }\end{array}$ & 6 \\
\hline 13 & $\begin{array}{l}\text { Scientific dan Legal Evidence: Aspek Kerusakan Lingkungan Akibat } \\
\text { Pertambangan }\end{array}$ & 6 \\
\hline 14 & $\begin{array}{l}\text { Scientific dan Legal Evidence: Aspek Kerusakan Lingkungan Akibat Illegal } \\
\text { Logging }\end{array}$ & 6 \\
\hline 15 & $\begin{array}{l}\text { Scientific dan Legal Evidence: Aspek Kerusakan Lingkungan Akibat Kebakaran } \\
\text { Hutan dan Lahan }\end{array}$ & 6 \\
\hline 16 & $\begin{array}{l}\text { Perkembangan Hukum Lingkungan Hidup dan Penerapan Prinsip-Prinsipnya } \\
\text { di Tingkat Internasional dan Nasional }\end{array}$ & 3 \\
\hline 17 & $\begin{array}{l}\text { Alternatif Penyelesaian Sengketa di Bidang Perlindungan dan Pengelolaan } \\
\text { Lingkungan Hidup (APS) }\end{array}$ & 3 \\
\hline \multicolumn{2}{|r|}{ Total Jumlah Jam Pelajaran } & 71 \\
\hline
\end{tabular}

Dengan diberikannya pelatihan sertifikasi lingkungan hidup kepada hakimhakim di lingkungan Mahkamah Agung termasuk kepada hakim PTUN, diharapkan PTUN dapat menjalankan fungsinya dalam menyelesaikan sengketa secara maksimal.
Dengan pemahaman lingkungan hidup yang lebih baik, diharapkan hakim dapat memeriksa sengketa lingkungan secara mendalam hingga substansinya terkait dengan aspek kelestarian lingkungan hidup. Berbeda dengan putusan-putusan hakim 
selama ini yang lebih mengedepankan aspek formal prosedural, dan kurang menyentuh aspek substansial. Sehingga bisa dikatakan perlindungan hukum yang diberikan oleh PTUN dalam kasus-kasus lingkungan adalah keadilan prosedural dan belum bisa menyentuh keadilan substansialnya.

Kendala dari aspek pelaksana hukum yang kedua adalah kendala keberadaan pengadilan sesuai dengan ketentuan peraturan perundang-undangan. Seharusnya di tiap kabupaten/kota terdapat Pengadilan TUN yang memeriksa dan memutus perkara TUN di tingkat pertama, dan setiap provinsi terdapat Pengadilan Tinggi TUN yang memeriksa dan memutus perkara TUN di tingkat banding. Namun demikian, hal ini terpenuhi sesuai ketentuan yang seharusnya. Ini dapat menjadikan kendala bagi seseorang atau badan hukum yang dirugikan oleh KTUN untuk dapat menggugat ke PTUN, jika di daerah belum terdapat PTUN atau PT TUN yang menangani sengketa. Hal ini menyebabkan pencari keadilan harus menempuh perjalanan yang panjang untuk dapat memperjuangkan hak-haknya, yang tentu saja akan menambah berat dalam memperjuangkan hak-haknya dari segi waktu, tenaga maupun biaya. Bagi yang tidak mampu hal ini menyebabkan yang bersangkutan enggan untuk mengajukan gugatan ke PTUN dan cenderung pasrah terhadap keadaan yang demikian.

Kendala pelaksana hukum lainnya adalah Pejabat TUN sebagai pihak tergugat yang harus melaksanakan Putusan Pengadilan TUN. Hingga saat ini pelaksanaan Putusan Pengadilan TUN diserahkan kesukarelaan Pejabat TUN untuk melaksanakannya, karena Putusan Pengadilan TUN kurang mempunyai daya paksa. Ketidaktaatan Pejabat TUN untuk melaksanakan Putusan Pengadilan TUN mengakibatkan PTUN kurang berfungsi untuk dapat memberikan perlindungan hukum yang maksimal bagi pencari keadilan. Jika Pejabat TUN tidak melaksanakan Putusan Pengadilan TUN, maka pihak penggugat atau pencari keadilan hanya akan menang di atas kertas dan tidak bisa menikmati kemenangannya sehingga pengorbanannya menggugat ke PTUN menjadi sia-sia.

\section{Penutup}

Fungsi PTUN dalam memberikan perlindungan terhadap kelestarian lingkungan adalah belum optimal. Putusan-Putusan Pengadilan TUN yang obyek sengketanya di bidang lingkungan hidup belum memberikan perlindungan kelestarian secara optimal, karena hakim cenderung bersifat prosedural formalistik dalam menggunakan pertimbangannya, dan kurang menyentuh substansi atau pokok perkaranya terkait dengan lingkungan hidup dan kelestariannya. Dalam beberapa Putusan Pengadilan TUN yang obyek sengketanya sama yaitu mengenai kelayakan atau ketidaklayakan lingkungan diputus secara bertentangan dan lebih memihak kepada pemilik modal besar daripada memberikan perlindungan terhadap kelestarian hutan. Belum optimalnya fungsi PTUN disebabkan adanya kendala-kendala yang meliputi kendala terhadap peraturan perundang-undangan, kendala terhadap asas-asas hukum, dan kendala terhadap pelaksana hukum.

Saran untuk mengatasi belum optimalnya fungsi PTUN adalah melakukan penyempurnaan peraturan perundang-undangan; memasukkan asas pembangunan berkelanjutan dan asas pencegahan dini sebagai dasar pengujian KTUN obyek sengketa dalam penyelesaian sengketa di PTUN; segera dibentuk Pengadilan TUN di tiap kabupaten/ kota dan Pengadilan Tinggi TUN di tiap provinsi; memberikan sanksi yang dapat dipaksakan kepada para pejabat yang tidak melaksanakan Putusan PTUN; dibentuk pengadilan khusus lingkungan di bawah Peradilan Tata Usaha Negara yang diharapkan mampu memeriksa dan mengadili sengketa secara mendalam dari aspek substansinya. 


\section{DAFTAR PUSTAKA}

\section{A. Buku}

Fajar, Mukti dan Yulianto Achmad, 2010, Dualisme

Penelitian Hukum Normatif dan Empiris, Pustaka Pelajar, Yogyakarta.

Muchsan, 1997, Sistem Pengawasan terhadap Perbuatan Aparat Pemerintah dan Peradilan Tata Usaha Negara di Indonesia, Liberty, Yogyakarta.

Mukhlish dan Mustafa Lutfi, 2010, Hukum Administrasi Lingkungan Kontemporer, Setara Press (Kelompok In-TRANS Publishing), Malang.

Pudyatmoko, Sri dan Riawan Tjandra, 1996, Peradilan Tata Usaha Negara Sebagai Salah Satu Fungsi Kontrol Pemerintah, Penerbitan
Universitas Atma Jaya, Yogyakarta.

Ridwan, H.R., 2003, Hukum Administrasi Negara, UII Press, Yogyakarta.

Soemitro, Rochmat, 1998, Peradilan Tata Usaha Negara, Refika Aditama, Bandung.

\section{B. Artikel Jurnal}

Effendi, Aan, "Penyelesaian Sengketa Lingkungan Melalui Peradilan Tata Usaha Negara", Perspektif, Vol. XVIII, No. 1, Januari 2013.

\section{Sumber Internet}

Wikipedia The Free Encyclopedia, Precautionary Principle, http://en.wikipedia.org, diakses 20 Mei 2014. 